\title{
EXPLORING FACTORS THAT INFLUENCE THE MAINSTREAMING OF GENDERED ENERGY INTERVENTIONS IN POOR URBAN ENVIRONMENTS: A STRUCTURED LITERATURE REVIEW
}

\author{
L. Oosthuizen ${ }^{1}$, I.H. de Kock ${ }^{1 *} \&$ J.K. Musango ${ }^{2}$
}

\section{ARTICLE INFO}

\section{Article details \\ Presented at the $31^{\text {st }}$ annual conference of the Southern African Institute for Industrial Engineering (SAllE), held virtually from 5-7 October 2020 . \\ Available online \\ Contact details \\ * Corresponding author imkedk@sun.ac.za \\ Author affiliations \\ 1 Department of Industrial Engineering, Stellenbosch University, South Africa \\ 2 School of Public Leadership Stellenbosch University, South Africa}

11 Nov 2020

ORCID ${ }^{\circledR}$ identifiers

L Oosthuizen

https://orcid.org/0000-0002-5385-9623

I.H. de Kock

https://orcid.org/0000-0003-4136-7418

J.K. Musango

https://orcid.org/0000-0001-9635-0002

DOI

http: / /dx.doi.org/10.7166/31-3-2421

\section{ABSTRACT}

Energy sectors are faced with the interconnected challenges of urbanisation and providing a growing population with accessible and sustainable energy that facilitates economic development, energy security, and poverty reduction. The Sustainable Development Goals address issues that include poverty, gender equality, energy, and sustainable cities, and highlight the need to improve the lives of poor communities and to address economic marginalisation. However, recent studies show that poor urban areas have a considerable number of femalelead households. Energy is a critical input for these households, resulting in women being increasingly vulnerable to unsustainable energy consumption patterns and energy insecurity. In this article, a structured literature review is conducted to investigate energy technologies that contribute to energy security among energy-poor women. The key factors to consider in the mainstreaming of a gender perspective into energy technology innovations are then identified and contextualised. How these factors can help achieve the sustainable development goals and contribute to ensuring sustainable energy sectors is also highlighted.

\section{OPSOMMING}

Energiesektore word gekonfronteer met die onderling gekoppelde uitdagings van verstedeliking en om 'n groeiende bevolking te voorsien met toeganklike en volhoubare energie wat ekonomiese ontwikkeling, energiesekerheid en amoede-vermindering fasiliteer. Die Doelwitte vir Volhoubare Ontwikkeling behandel kwessies soos armoede, geslagsgelykheid, energie, en volhoubare stede en beklemtoon die noodsaaklikheid om die lewens van arm gemeenskappe te verbeter en ekonomiese marginalisering aan te spreek. Onlangse studies toon egter dat arm stedelike gebiede ' $n$ aansienlike aantal huishoudings met vroue aan die hoof het. Energie is ' $n$ kritieke inset vir hierdie huishoudings wat veroorsak dat vroue toenemend kwesbaar is vir onvolhoubare energieverbruikpatrone en energie-onsekerheid. In hierdie artikel word 'n gestruktureerde literatuuroorsig uitgevoer om energietegnologieë te ondersoek wat bydra tot energiesekerheid onder energie-arm vroue. Die sleutelfaktore om in ag te neem vir die integrasie van ' $\mathrm{n}$ geslagsperspektief in energie-tegnologie-innovasies word vervolgens identifiseer en gekontekstualiseer. Hoe hierdie faktore kan help om die Doelwitte vir Volhoubare Ontwikkeling te bereik en kan bydra tot die versekering van volhoubare energiesektore, word ook uitgelig.

Energy is an essential input in the lives of men and women and enables them to perform daily household activities. Adequate energy is critical to meeting basic needs such as cooking, lighting, and heating [1]. The inability to meet basic household needs adequately results in energy insecurity, which causes chronic cycles of hardship and poverty [2]. Oparaocha and Dutta [3] state that access to modern energy is an essential prerequisite for alleviating energy poverty and supporting sustainable human development, thus 
highlighting two parallel elements of energy access: (i) sustainable energy ${ }^{*}$, which aims to support sustainable human development; and (ii) energy security ${ }^{\dagger}$, which aims to combat energy poverty. To achieve energy security, the widespread issue of energy poverty, which leaves three billion people relying on inefficient and polluting cooking systems [4], is challenged. One-third of the world's population depends on traditional energy sources and uses inefficient energy technologies such as unventilated stoves $[5,6,7]$. Together with rapid urbanisation [6], these unsustainable energy consumption patterns are keeping the poor impoverished.

The position of women in various levels of governance (i.e., national, regional, community, and household levels) makes for an inevitable link between women and energy poverty in developing countries. This link is based on how energy poverty disproportionally affects women and girls [3]. The case of the femaleheaded household cuts across being unemployed, underemployed, and poorly paid [9]. Women and children spend a significant amount of time collecting and burning wood and charcoal to heat their homes and prepare meals $[9,10]$. Men and women have unequal access to energy resources, energy sources, and decision-making power in the household $[3,8,10,12]$. And women represent less than 40 per cent of the employed, and occupy about 25 per cent of managerial positions in the world [13].

It is highly unlikely that the world will be able to achieve the 17 sustainable development goals (SDGs) without also achieving gender equality and the empowerment of women ${ }^{\ddagger}$ [13]. Thus, for sustainable development to become a reality in developing countries, the battle between energy poverty and gender inequality necessitates increased attention to gender equality in the energy sector. A growing body of evidence supports the notion that increasing access to modern energy can significantly impact women's lives [3]. This body of evidence highlights the need to transform the energy industry into a vehicle for promoting gender equality.

As a way to transform the energy industry, the United Nations Fourth World Conference on Women in 1995 called for action to mainstream gender in all policies and programmes, and to analyse the differentiated effects of energy interventions on men and women before making decisions [14]. Mainstreaming gender is a strategy that intends to transform the energy industry by addressing the inequality of women, and implies a shift in the role of women in the energy sector [15]. As an attempt to encourage gender mainstreaming internationally, the United Nations Commission on Sustainable Development recommended in 2011 that governments support equal access for women to sustainable and affordable energy technologies through needs assessments, energy planning, and policy formulation at the local and national levels [16].

In the light of these interventions, mainstreaming gender in the energy sector is defined as a strategy that assesses a project's potential impacts on men and women on all levels, and in all areas, to understand how energy initiatives differently affect men and women along the energy value chain (EVC) [9]. The aim of mainstreaming gender is described in terms of a twin-track strategy, with two components [3]: (i) integrating men's and women's concerns in all energy policies, projects, and programmes to achieve gender equality; and (ii) implementing targeted activities in energy interventions to empower women. Women should also be empowered to be active stakeholders and participants in the EVC [17], and actions to mainstream gender should be sustained throughout every phase of the energy project cycle [9].

Nevertheless, regardless of a multitude of mainstreaming gender commitments, interventions, and attempts in the energy sector, very few energy programmes include gender mainstreaming in their frameworks [3], and gender inequalities are seldom addressed as an essential part of national energy policies and programme design [17]. In the Global South, national energy policies are often gender-blind despite efforts to put gender on the energy agenda, and a growing body of literature shows that, in practice, energy is a highly gendered phenomenon [18]. Various instances are recorded in the literature where mainstreaming gender is considered only at entry to, rather than throughout, the entire project cycle $[9,10,19]$. Thus,

Sustainable energy is produced and used in such ways that it supports long-term human development in all social, economic, and environmental spheres, and incorporates multiple stakeholders in decision-making processes [6].

$\dagger \quad$ Energy security is defined as the "availability of energy at all times in various forms, in sufficient quantities, and at affordable prices" [6]

‡ Many societies have biased perceptions of the term 'gender equality', resulting in gender equality policies being viewed as controversial and thus being rejected [8]. However, 'empowerment' may be seen as a way to reach equality as well as an outcome of the achievement of equality, making it a process as well as a state, and thus a more acceptable term [8]. In this paper, 'women's empowerment' is defined as the process by which gender equality is achieved, as well as the result of the achievement of gender equality that supports the ultimate goal of sustainable development 
even though mainstreaming gender is a promising strategy with high aims and transformative capabilities, several gaps hinder the effective and comprehensive implementation of mainstreaming gender in energy interventions.

This structured literature review considers the literature on mainstreaming gender as a strategy to promote gender equality along the EVC ultimately to support sustainable communities and cities in urban poor environments, which is linked to SDG11. The aim of this structured literature review is to consider systematically the available literature on the mainstreaming of gender in energy interventions ${ }^{\S}$ to identify the interconnected factors ${ }^{* *}$ that influence gender mainstreaming, as well as the gaps hindering its effective implementation in the energy sector. The objectives of this structured literature review are: (i) to identify the available literature about the mainstreaming of gender in energy interventions; (ii) to synthesise the literature and identify the key factors that influence the mainstreaming of gender in energy interventions; and (iii) to analyse these factors to understand the linkages among them; and the gaps in gender mainstreaming approaches that require further research.

\section{APPROACH AND METHODS}

This paper reports on a structured literature review, guided by the preferred reporting items for systematic reviews and meta-analyses (PRISMA) methodology defined by Moher et al. [20] and elaborated on by Liberati et al. [21]. A structured literature review collects all empirical evidence that matches pre-specified eligibility criteria to answer specific research questions [22]. Although this method is time-consuming and labour-intensive, it provides high quality, efficient results in many engineering literature review works [2332]. The evidence- informed PRISMA methodology is adopted to ensure transparency, structure, and clear reviewing of the available literature [20].

The high-level approach for this structured literature review is illustrated in Figure 1 for (i) the four consecutive phases according to which this review is conducted; (ii) the steps included in each phase; and (iii) the associated processes in the PRISMA flowchart for each phase (adapted from Moher et al. [20]). At the left of Figure 1, the sections of this paper that cover each phase are indicated.

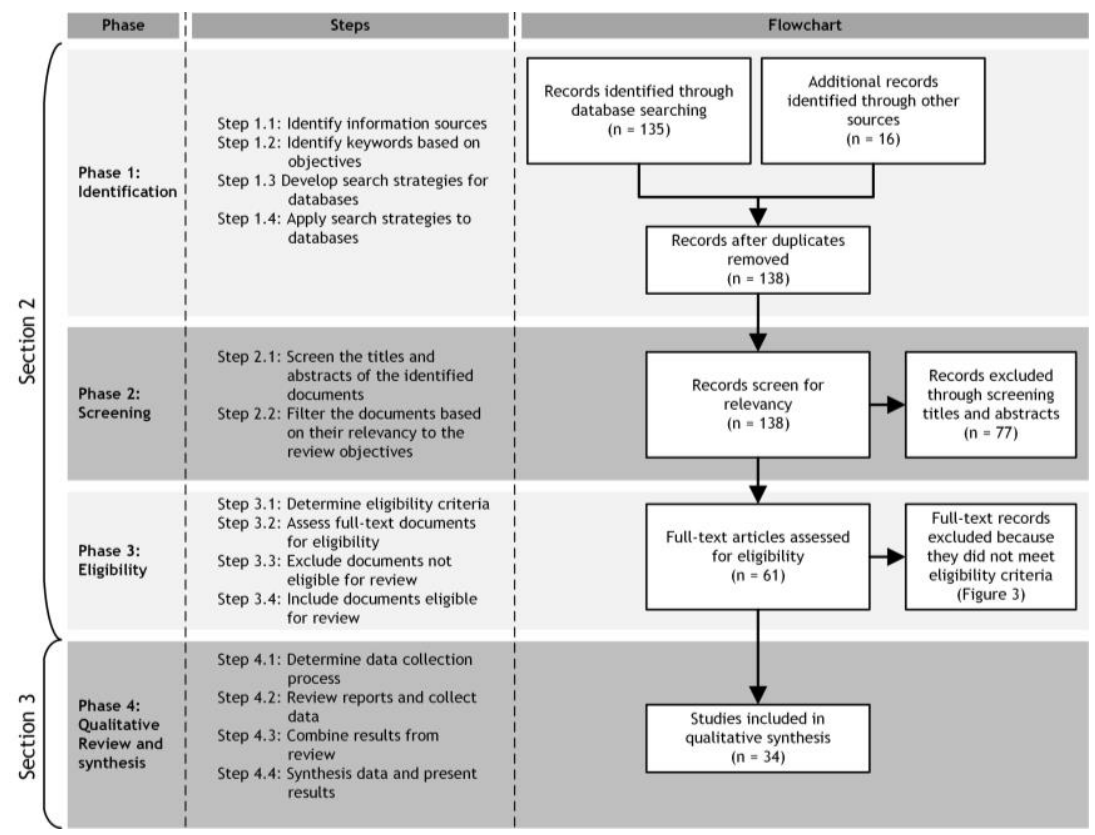

Figure 1: The high-level approach, adapted from Moher et al. [20]

For the sake of comprehensiveness, 'energy interventions' is used as a collective term that includes the following terms: energy technology innovations, energy innovations, energy technologies, energy services, and energy initiatives.

* For the sake of comprehensiveness, 'factors' is used as a collective word, and includes the following words: aspect, reason, cause, concept, dynamic, consideration, dimension, condition, facet, feature, element, component, indicator, impact, characteristic, practice, and perspective. 
The first three phases of this structured literature review are presented next. Subsection 2.1 explains Phase 1 , concerned with the identification of information sources, keywords, and search strategies. Subsection 2.2 discusses Phase 2 , in which the screening process is explained, as well as Phase 3 , which covers the development and execution of the eligibilityassessment.

\subsection{Phase 1 (Identification)}

In Phase 1 of the review, the information sources and keywords were identified, followed by the development and execution of the search strategies. In the first step of Phase 1, a comprehensive set of databases with high coverage of the available literature was identified. The first and main source of literature was the Scopus database because it is the largest repository of peer-reviewed literature with over 75 million records and 5000 publishers covering every aspect of science [34]. Google Scholar was identified as the second source of literature because it is recognised as the largest and most frequently used academic search engine [35]. The ENERGIA publications database was identified as the third source of literature, since - with nine teams of researchers in 12 countries - ENERGIA has built an evidence base that contributes to improving energy security and understanding its gendered dimension [36], which directly links to the focus of this paper.

All dates, general topics, and languages were searched for in the Scopus database to ensurefull coverage [31]. For Google Scholar and ENERGIA, the search was limited to (i) literature from the years 2015 to 2019, to focus on the most recent works and to prevent the bias that older works may introduce [37]; and (ii) English documents (there is insufficient evidence to conclude that language-restricted meta-analyses lead to biased results [38]). Limitations of the search included the inaccessibility of documents, the language restriction on the Google Scholar search, and the date restrictions on the Google Scholar and ENERGIA databases. The date on which the information sources were last searched is 20 April 2020.

In the second step of Phase 1, the keywords were identified. This step was initiated by examining recent works on gender mainstreaming and energy interventions $[3,39,44]$. This preliminary examination resulted in the identification of keywords and search terms around combinations of keywords that relate to gender mainstreaming, energy interventions, and factors that influence gender mainstreaming in the energy sector.

In the third step, the search strategies were developed from the keywords. The information sources and corresponding search strategies are summarised in Table 1.

Table 1: The information sources and corresponding search strategies

\begin{tabular}{|c|c|}
\hline $\begin{array}{l}\text { Information } \\
\text { Source }\end{array}$ & Search strategy \\
\hline $\begin{array}{l}\text { Scopus } \\
\text { database } \\
\text { (all dates) }\end{array}$ & $\begin{array}{l}\text { The outlined query of the search strategy is: TITLE-ABS-KEY ( factor* OR aspect* OR reason* OR } \\
\text { cause* OR concept* OR dynamic* OR consideration* OR dimension* OR condition* OR facet* OR } \\
\text { feature* OR element* OR component* OR indicator OR impact* OR character }{ }^{*} \text { OR practice* } \\
\text { OR perspective* ) AND TITLE-ABS-KEY ( "energ* intervention*" OR "energ* technolog*" OR "energ* } \\
\text { service*" OR "energ* innovation*" OR "energ* initiative" OR "energ* } \\
\text { "securit*" OR "energ* polic*" OR "energ* povert*" OR "household* energ*") AND ALL ("gender* } \\
\text { mainstream*" OR "mainstream* gender") }\end{array}$ \\
\hline $\begin{array}{l}\text { Google Scholar } \\
(2015-2020)\end{array}$ & $\begin{array}{l}\text { The Scopus search strategy was adapted for Google Scholar. The advanced search used in Google } \\
\text { Scholar is: "energy intervention" OR "energy technology" OR "energy innovation" OR "energy } \\
\text { initiative" OR "energy policy" OR "household energy" OR "energy service" OR "energy insecurity" } \\
\text { OR "energy security" OR "energy poverty" AND "gender mainstreaming" }\end{array}$ \\
\hline $\begin{array}{l}\text { ENERGIA } \\
\text { publications } \\
(2015-2020)\end{array}$ & $\begin{array}{l}\text { The publications database was screened for relevance to gender mainstreaming and its } \\
\text { implementation in the energy sector. }\end{array}$ \\
\hline
\end{tabular}

\subsection{Phase 2 (Screening) and Phase 3 (Eligibility)}

Phase 1 returned a total of 151 items (referred to as identified literature) matching the search strategy. Phase 2, according to the PRISMA methodology, is the screening process that includes removing duplicates and screening the titles and abstracts of the identified literature to identify irrelevant records that should be excluded from the review [20]. To eliminate duplicates, a preliminary data refinement on the titles [34] was conducted. Thereafter the titles and abstracts of the remaining 138 documents were screened $[34,37,45]$. Based on this screening, documents were excluded from the review in the cases of (i) the unavailability of the full-text document; or (ii) the literature type being a thesis, unpublished report, poster, presentation, white literature, or webpage. This screening process resulted in the removal of 77 documents and 61 documents being subject to the eligibility assessment in Phase 3, which is explained next. 
In Phase 3, the eligibility assessments of the 61 full-text documents were conducted using the eligibility criteria (Figure 2). The whole content of a document was browsed and, based on the eligibility criteria $[34,37,45]$, it was determined whether the document applied and detailed gender mainstreaming in energy interventions, or whether it simply mentioned gender mainstreaming in general. From the 61 documents assessed for eligibility, 27 did not meet the eligibility criteria and were excluded from the qualitative analysis. The remaining 34 documents were included in the qualitative review and synthesis, provided in Section 3.

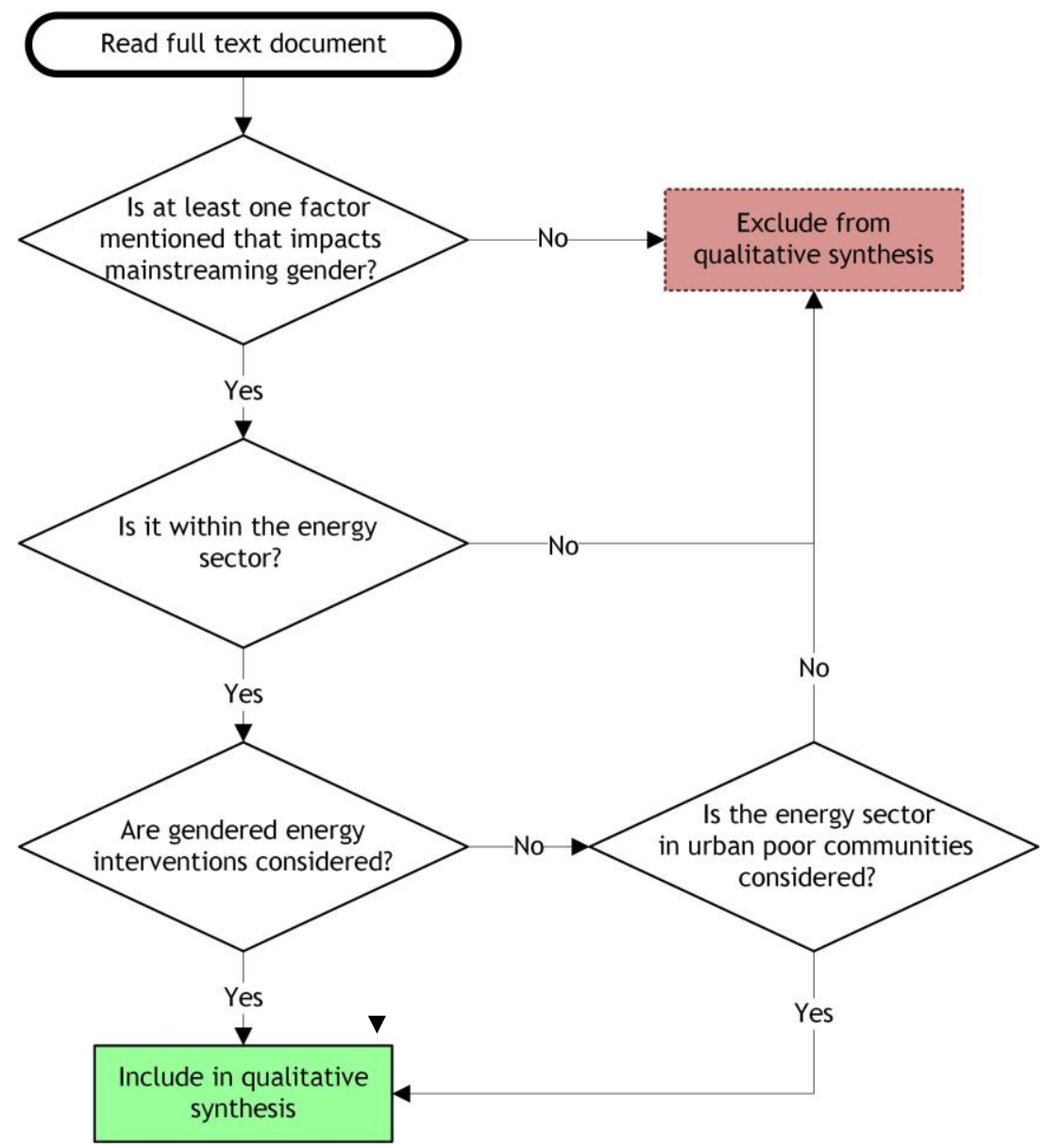

Figure 2: The eligibility criteria for Phase 3

Phase 3, explained in subsection 2.2, concluded the final list of 34 documents for data analysis and synthesis. A narrative synthesis approach was adopted and the data was synthesised using thematic synthesis and analysed using content analysis [46]. The thematic synthesis approach was adopted to identify the main themes emerging from the literature, and to organise the literature around the key themes $[46,47]$. The content analysis that followed was conducted to categorise the data and the frequency of each theme to identify the key findings $[46,48]$. The narrative synthesis is provided in Subsection 3.1.

\subsection{Narrative synthesis}

The first phase of the narrative synthesis was to identify the emerging themes across the final set of literature through thematic synthesis. Table 2 organises these themes in terms of the identified factors present in the literature to bring about the mainstreaming of gender in the energy sector. The number of documents that supported the inclusion of the factor (Column 3 in Table 2) represents the number of times the theme occurred in the final set of reviewed literature. 
Following the thematic synthesis was a content analysis (subsections 3.1.1 - 3.1.11) of the identified factors that highlighted the key findings of each factor. The content analysis was supported by additional conceptual mapping [46] that aimed to explore relationships within and among specific factors.

Table 2: Identified factors that influence mainstreaming gender in energy interventions

\begin{tabular}{|l|l|l|}
\hline Factor & Complete list of supporting references & Number of documents \\
\hline Stakeholder participation & {$[36,49-59]$} & 13 \\
\hline Perspective & {$[8,49,50,60,61]$} & 5 \\
\hline Governance & {$[14,16,17,22,36,50,52,54,56]$} & 9 \\
\hline Policy-level factors & {$[8,22,36,50,52-54,55,57,60-62,64-66]$} & 15 \\
\hline Socio-cultural factors & {$[9,17,18,36,50,52,54,56,57,59,64-68,70,71]$} & 17 \\
\hline Capacity building & {$[3,14,16,17,36,50,52,54,56,58,60-64,66-69]$} & 20 \\
\hline Resource availability & {$[14,36,50-52,54,62-64,66,68]$} & 11 \\
\hline Educational opportunities & {$[3,54,56,58,62,63,65]$} & 7 \\
\hline Infrastructure availability & {$[36,62,63]$} & 3 \\
\hline Energy project cycle & {$[3,8,9,14,17,18,36,50,51,53-57,60-62,64,68,69,72]$} & 21 \\
\hline Women's empowerment & {$[3,16,17,22,54,55,59,60,64,66]$} & 10 \\
\hline Agency & {$[36,53,54,66,71]$} & 5 \\
\hline Knowledge management & {$[53,57,64]$} & 3 \\
\hline Dissemination activities & {$[64]$} & 1 \\
\hline Access to energy & {$[55,66]$} & 2 \\
\hline Productive use of energy $(\mathrm{PUE})$ & {$[63]$} & 1 \\
\hline Barriers & {$[8,16,52,54,67,68]$} & 6 \\
\hline Gender analysis tools & {$[8,9,13,14,16,17,22,36,50-58,60,62-64,67-69,71]$} & 25 \\
\hline
\end{tabular}

\subsubsection{Stakeholder participation}

The first identified factor that influences mainstreaming gender is stakeholder participation. The importance of including parties from global, national, regional, community, and household levels is explicitly emphasised by 12 studies. However, all 34 studies mention the importance of interaction among different actors. Also, a gap is identified that recognises the need for diverse participation and collaborative relationships among actors from all levels for gender issues to be mainstreamed. The literature reveals that multi-stakeholder participation is an enabler, catalyst, and core element for the success and sustainability of gender mainstreaming.

\subsubsection{Perspective}

This multi-dimensional factor is mentioned in five studies, which reveal that gender mainstreaming should not be viewed from one perspective, but that a multi-perspective lens is required for gender equality to be achieved in energy interventions. One study recommends viewing mainstreaming gender from economic, environmental, and social perspectives, while another suggests affordability, availability, and safety perspectives. Two studies highlight context-specific perspectives that incorporate mainstreaming gender into the assessment of needs and priorities, and subsequently to adopt a bottom-up approach. A holistic interpretation of this literature is illustrated in Figure 3, which integrates the different perspectives by viewing gendered energy through a context-specific lens in terms of an economic, environmental, and social perspective, considering the availability, affordability, and safety dimensions of each perspective.

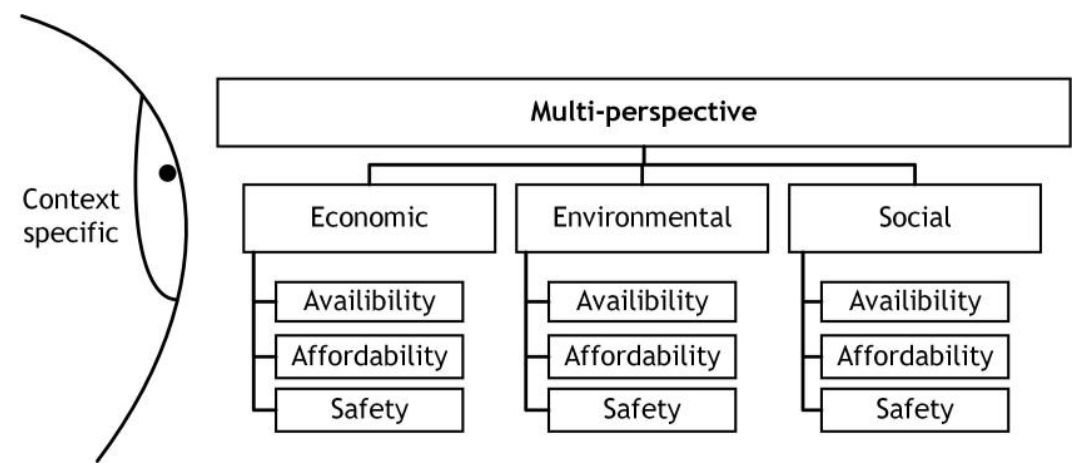

Figure 3: Conceptual mapping of the perspective factor

\subsubsection{Governance}

The governance factor is supported by nine studies. This factor encompasses the process of decisionmaking, and the actors that oversee these processes and strategies so that decisions are correctly 
implemented. It is strongly connected to both the stakeholder participation factor and the policy-level factor. The literature reveals that governance should be considered at the global, macro, meso, and micro levels. A defining sub-factor of governance is political will, which involves political commitment and institutional support and their importance in the facilitation of gender mainstreaming.

\subsubsection{Policy-level factors}

The policy-level factor is supported by convincing evidence, with 15 studies clearly stating the direct correlation between effective, enforceable policies and the successful execution of mainstreaming gender. Seven studies discuss the criticality of implementing mainstreaming gender at all levels to ensure coherence and alignment among gender policies and energy policies, while four studies highlight that gender should be mainstreamed in public and government policy development to build institutional capacity among the different actors. Three studies emphasise that energy policies should undergo gender analysis to determine synergies, gaps, and alignment with men's and women's different needs. All 15 studies stress the lack of sufficient gender-analytical tools to aid in the formulation of comprehensive gender mainstreaming and energy policies. Figure 4 illustrates the multi-dimensional nature of the policy-level factor for gender mainstreaming policies and energy policies, how they align with each other, and how they necessitate considerations from each sphere. The following gaps are emphasised in the literature: (i) a disconnect between policy formulation and implementation due to a lack of gender-disaggregated tools and frameworks; and (ii) viewing the government as an obstacle rather than a national mediator, leading to attempts to bypass government structures, and subsequently causing a deficit in the implementation capacity of gender mainstreaming in interventions.

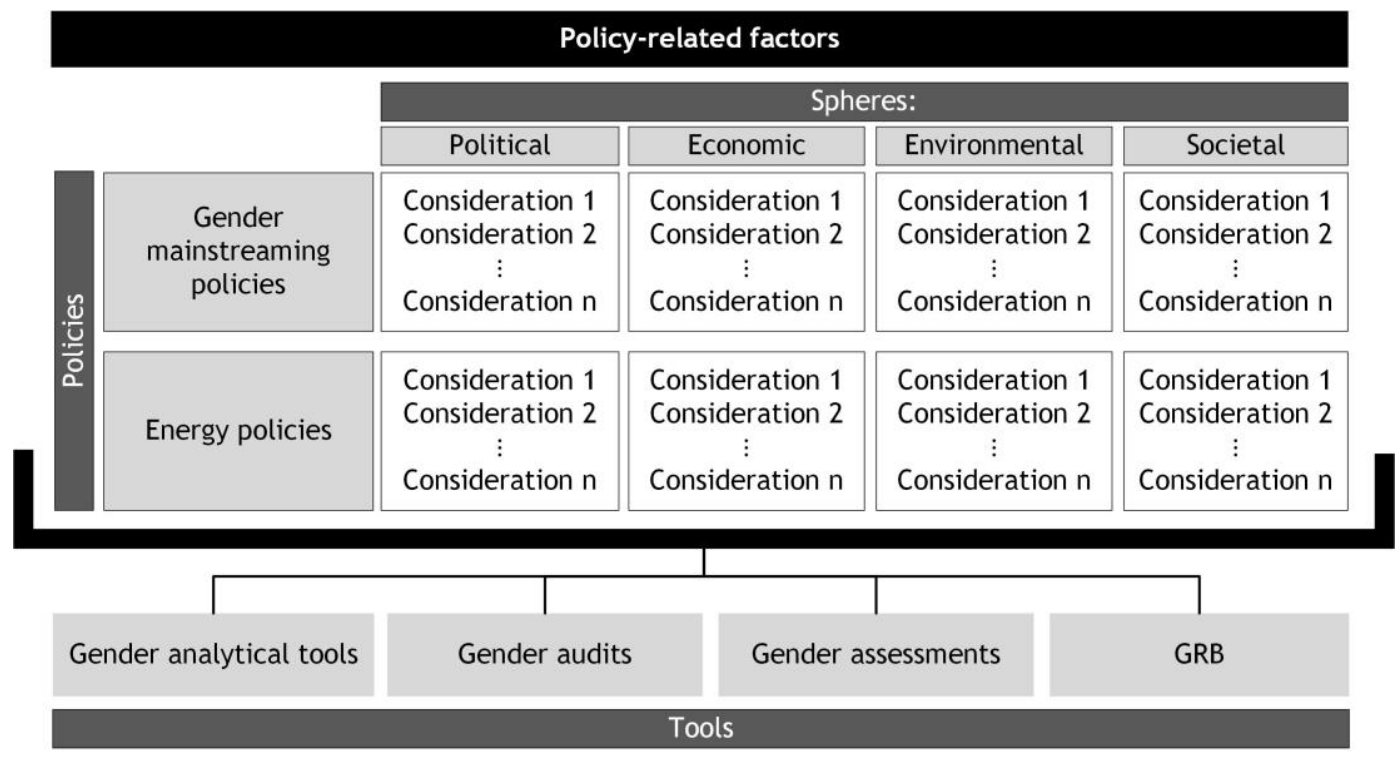

Figure 4: Conceptual mapping of the policy-level factor

\subsubsection{Socio-cultural context}

Socio-cultural context is another factor supported by robust evidence, with 17 studies explicitly highlighting the impact of socio-cultural context on gender mainstreaming. Socio- cultural factors encompass (i) household dynamics, norms, and roles; (ii) market-related factors such as skills, market power, mobility, access to finance, and gender roles; (iii) country-specific contextual factors such as religion, culture, and energy needs; and (iv) perceptions of women's roles in society. The literature reveals that socio-cultural factors have been incorrectly incorporated into gendered energy interventions, which has led to ineffective gender mainstreaming. Causes for this problem are revealed to be (i) the challenging nature of the inequalities in the socio-cultural context; (ii) the use of top-down approaches by national and regional actors, resulting in misperceptions of the actual differentiated needs of men and women; and (ii) a lack of gender-disaggregated data and gender analytical tools that provide clear, unbiased evidence of the real energy needs and demands in urban poor communities.

\subsubsection{Capacity building, resource availability, educational opportunities, and infrastructure availability}

Capacity building, resource availability, educational opportunities, and infrastructure availability are all interconnected, interdependent factors with robust evidence supporting their impact on gender 
mainstreaming. Capacity building alone is highlighted by 20 studies, with resource availability supported by 11 studies, educational opportunities mentioned by seven, and infrastructure availability referred to by three. Despite their interconnectedness, these four factors were individually identified in the review, and separately emphasised in different studies. Consequently, they entail different sub-factors and they differ in essence; however, they should not be considered alone. Figure 5 is a holistic representation of these four factors - what each one entails, and how they relate to one another. The importance of a systems perspective is emphasised. The overarching gap identified in the literature is the lack of technical capacity in the energy sector, which limits women from participating in entrepreneurship, enterprises, and decisionmaking roles. This gap is reflected in Figure 5 with the Enabler arrows, indicating that, for community stakeholders to participate in the EVC as energy experts or policy experts, the primary level of capacity building (concerning educational opportunities), should first be realised, before engaging in advanced levels of capacity building that enable participation in entrepreneurship, enterprises, and decision- making roles.

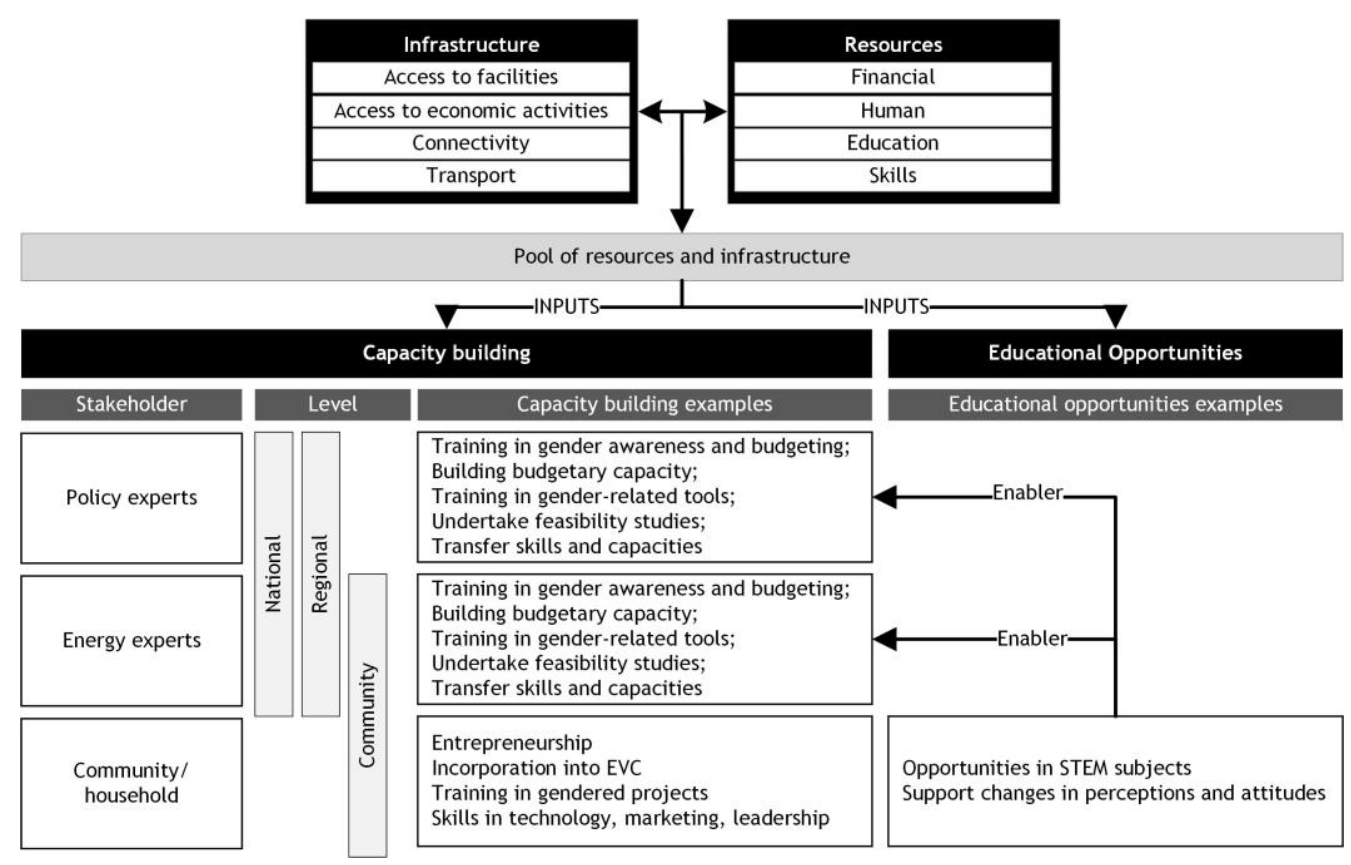

Figure 5: Conceptual mapping of capacity building, resource availability, educational opportunities, and infrastructure availability.

\subsubsection{Knowledge management and dissemination activities}

Knowledge management and dissemination activities are supported by three studies and one study respectively, and their significance to gender mainstreaming is embodied in the literature. These two factors are considered on international, national, regional, and household levels. The studies describe dissemination activities as mechanisms by which information is generated and shared, and knowledge management as the approaches used to share and strengthen networks. Knowledge management and dissemination activities aid in the development of a transparent, coherent body of evidence that informs decision-making, provides a common ground for actors from all levels to engage and exchange knowledge, and produces meaningful information to transform into gender-disaggregated data. The literature highlights the mismatch between gender knowledge and technical engineering knowledge, because researchers tend to be more from social science than from engineering. This gap highlights: (i) the immense need for collaboration and knowledge sharing between the social science disciplines and the engineering disciplines; and (ii) the need for a multi-disciplinary team of stakeholders in the implementation of gender mainstreaming in every phase of the project cycle.

\subsubsection{Energy project cycle, women's empowerment, and agency}

The energy project cycle incorporates the entire EVC and all its phases, as illustrated in Figure 6. This factor is supported by 21 studies that emphasise the correlation between the energy project cycle and mainstreaming gender. The literature repeatedly highlights that gender mainstreaming should be embedded and institutionalised in every phase of the energy project cycle through equal participation in the decisionmaking processes. The literature further highlights: (i) the involvement of government authorities; (ii) the 
need for supportive regulations; and (iii) institutional capacity that enables a gender-responsive organisational culture and creates an enabling environment where women have opportunities to empower themselves. Figure 6 shows the energy project cycle, examples of supportive tools and elements for each phase, the enabling environment in which the energy project cycle should ideally operate, and how the entire energy project cycle in the enabling environment feeds into women's empowerment.

Agency, a factor strongly associated with women's empowerment, is described in the literature as the ability of women to define goals, act on them, and have a voice. Five studies reveal a link between agency and gender mainstreaming and support the notion that agency should be redefined as transformative, and not just as effective. The literature emphasises the need to provide women with more agency and choice, instead of simply facilitating access to energy, as in the case of development aid.

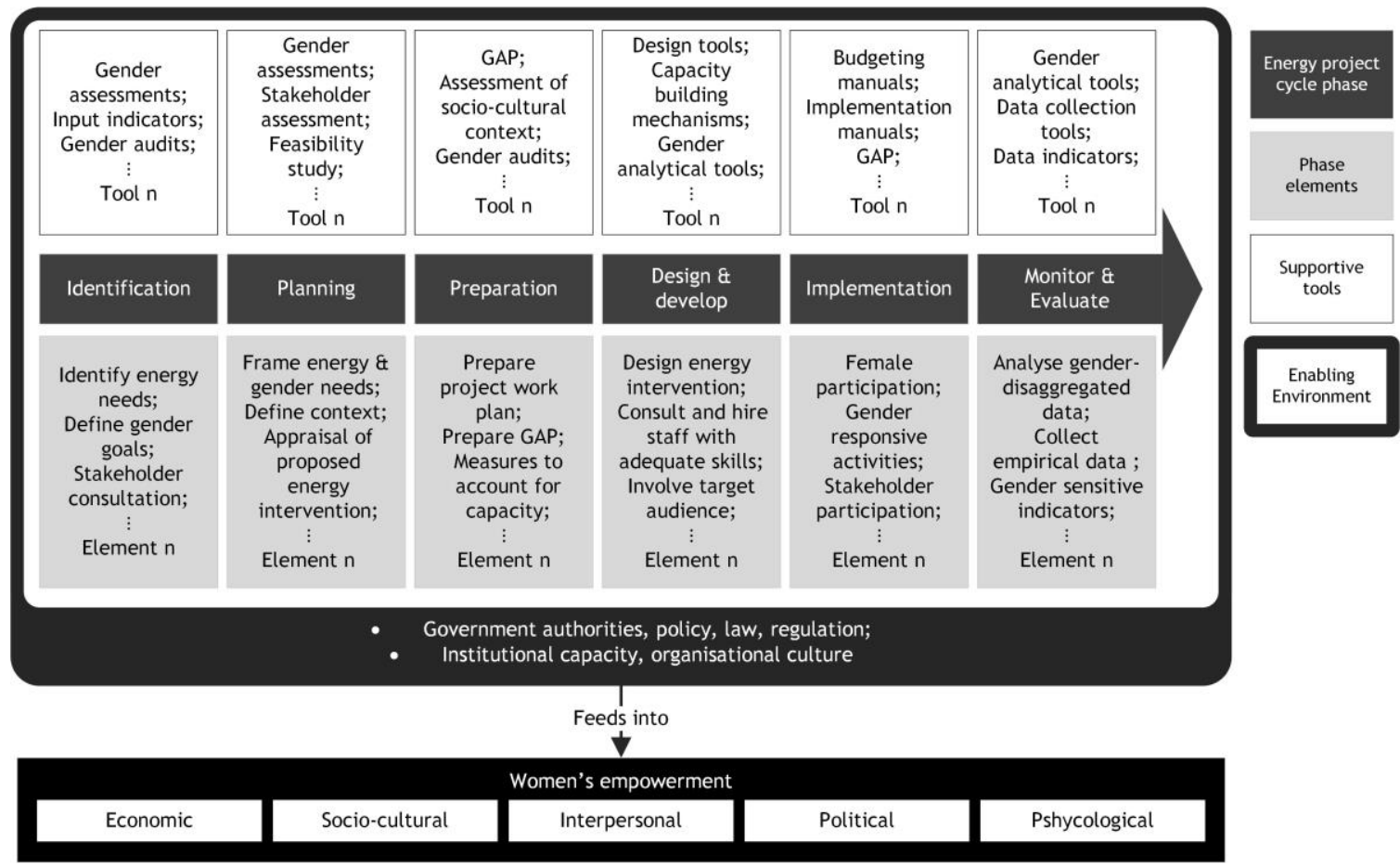

Figure 6: Conceptual mapping of the energy project cycle and women's empowerment

Based on the evidence from the review, the gaps in the energy project cycle are shown to be (i) the poor representation of women in decision-making positions at all levels; (ii) a lack of empowerment opportunities in which women can make their needs known; (iii) inadequate gender-disaggregated data and gender analytical tools that serve as the basis for informed, evidence-based decision-making; (iv) the exclusion of gender mainstreaming from energy project frameworks and energy policy frameworks; and ( $v$ ) a gap between energy policy and the practical context of men and women who need and use energy.

\subsubsection{Access to energy and productive uses of energy}

Access to energy and the productive use of energy (PUE) are explicitly mentioned in three studies as impacting factors in the implementation and success of gender mainstreaming. Evidence supports the influence of access to energy on the productivity of women and on educational opportunities. Also, evidence highlights the influence of PUE on the reliability of energy supply.

\subsubsection{Barriers}

The barriers factor is supported by six studies, and includes the factors hindering the successful, sustainable implementation and execution of mainstreaming gender in the energy sector. The barriers factor encompasses a range of the identified factors but views them from a perspective that considers the hindering effect they might have on gender mainstreaming if they are not sufficiently considered or managed in the strategy. The qualitative review identified three barrier levels and three barrier dimensions that should be considered at each level, as illustrated in Figure 7. 

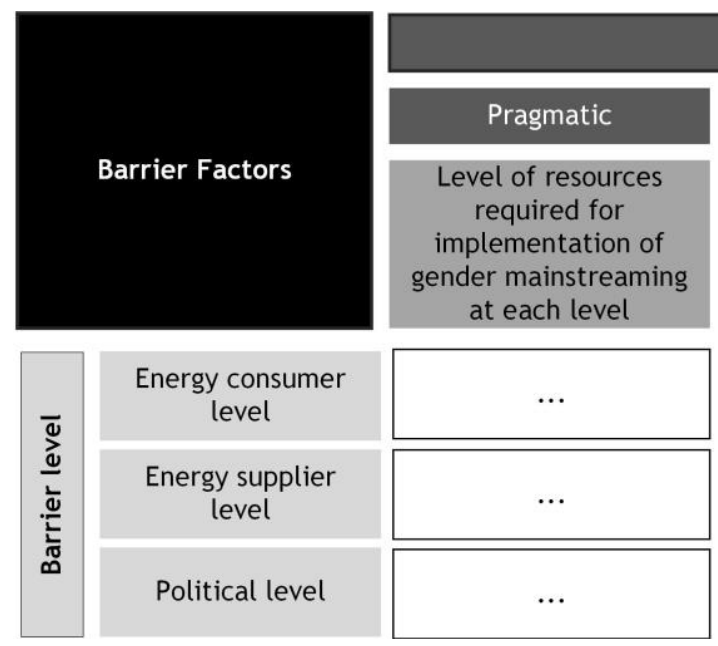

Energy consumer level

Energy supplier level

Political level

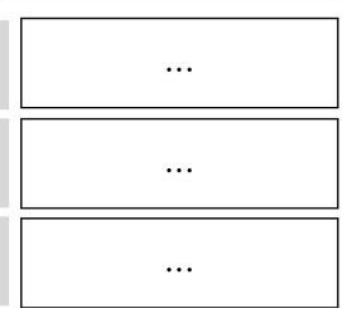

Barrier dimensions

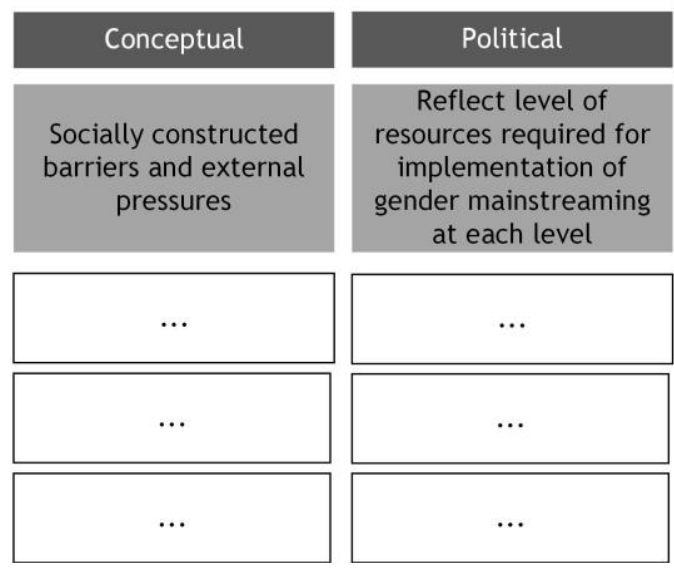

Figure 7: Conceptual mapping of the barriers factor

\subsubsection{Gender analytical tools}

Last, gender analytical tools are explicitly supported by 25 studies. Gender analytical tools are those that gather, assess, analyse, evaluate, and process the data received from gender-sensitive indicators, genderdisaggregated data, gender-sensitive stakeholder analyses, and participatory techniques. These tools are vital for the mainstreaming of gender in energy interventions and should ideally inform every phase of gender mainstreaming in the energy project cycle. However, a major problem mentioned in the literature is the lack of suitable gender-analytical tools to gather and process gender-sensitive data in a way that makes mainstreaming in energy planning straightforward. And because the focus of gender tools has been on empowerment, and not on actual gender needs and demands, the standard gender tools do not question the real gender goals, and do not provide indicators with which to assess the success of gender mainstreaming in energy interventions. Gender analytical tools, based on the evidence from the review, were identified as a major impacting factor in the success of gender mainstreaming, and the lack of available tools and the need for gender-disaggregated data is one of the main reasons that bottom-up approaches to gender equality have not yet been fully and effectively realised.

\subsection{Analysis of interconnected factors}

The narrative synthesis in sub-section 3.1 specified and explained the factors identified in the reviewed literature that influence the mainstreaming of gender in the energy sector. The content analysis and conceptual mapping highlight the interconnectedness of these factors. The synthesis reveals that no factor should be considered individually in the implementation of gender mainstreaming, but that the factors are interdependent and should be analysed, evaluated, and managed coherently. In this section, the interconnectedness of the factors is affirmed through the development of a network graph (Figure 8) using HTML, CSS, and JavaScript software. Each factor is represented by a circle, the size of which exemplifies the number of studies that support that specific factor. The links between the circles represent the connections among the factors in the final set of the literature (e.g., if a piece of literature has a focused section on gender analytical tools and makes reference to the energy project cycle as an attempt to elaborate on gender analytical tools, there would be a link between gender analytical tools and the energy project cycle). The four cross-cutting themes in the literature are revealed in Figure 8 by the four biggest circles, which also have the most connections with other factors: capacity building, socio-cultural factors, the energy project cycle, and gender analytical tools.

Figure 8 serves as a conceptual framework to emphasise how the identified factors that influence the mainstreaming of gender in energy interventions are all connected and how, in order to support gender mainstreaming in the energy sector, a single factor may be developed and improved by considering the specific factor in relation to those factors with which it has connections. Last, Figure 8, which may also be seen as a conceptual summary of the results of this structured literature review, will be used as the groundwork for future research that will focus on linking the critical factors to the energy project cycle in an attempt to support the implementation of gender mainstreaming throughout the entire energy project cycle. 


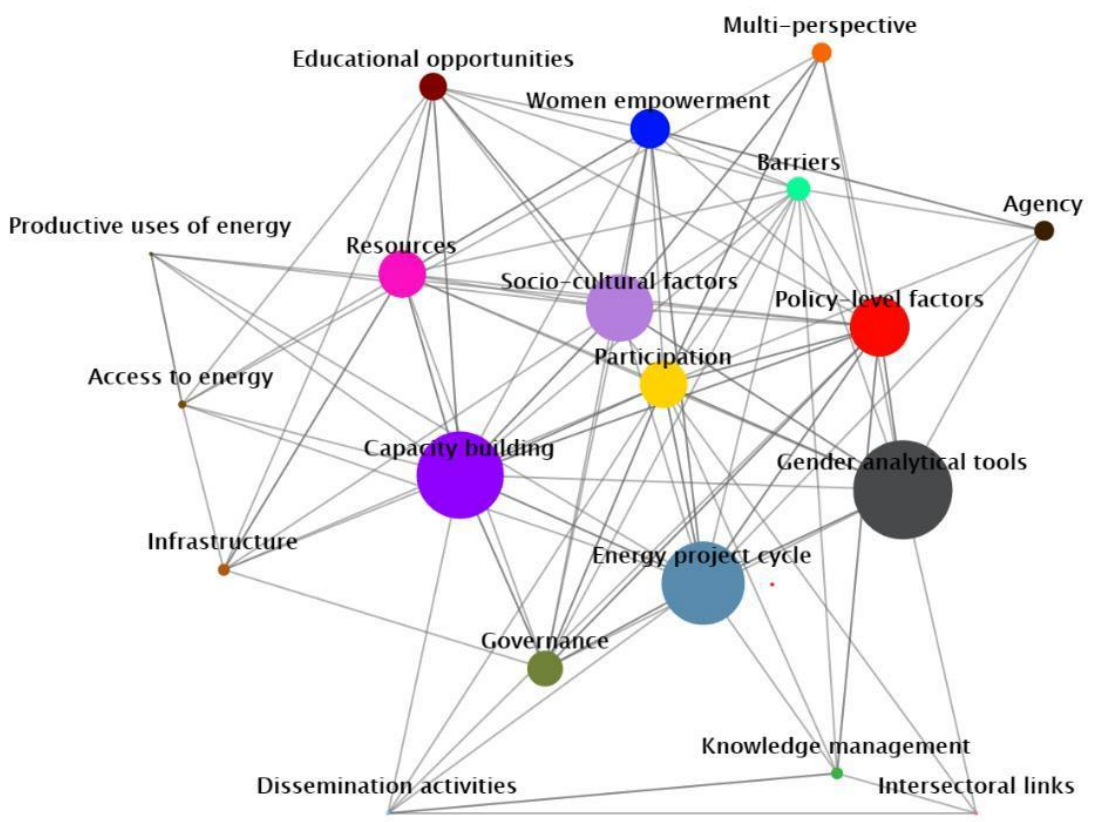

Figure 8: Network graph showing the interconnectedness of the identified factors

\section{CONCLUSION}

First, this structured literature review aimed to examine the available literature on the mainstreaming of gender in energy interventions to identify the key factors that influence gender mainstreaming. Second, the aim was to analyse these factors to understand how they are linked, and to identify the gaps in gender mainstreaming approaches that require further attention. In this structured literature review, 18 factors were identified in the literature that bring about the mainstreaming of gender in the energy sector; these factors were subsequently synthesised and analysed. Generalised learning was drawn from the literature, and approaching mainstreaming gender in the energy sector through a systems thinking lens - one that shows how the constituent parts of gender mainstreaming interrelate, and how this strategy will work over time in the context of sustainable development in the energy sector - was demonstrated to be a critical finding. This review also identified the gaps in the gender mainstreaming literature that hinder its effective implementation in the energy sector. The insights of this review provide the theoretical foundation for future in-depth research about the implementation of gender mainstreaming throughout the energy project cycle. The goal of future research is to support sustainable development by making a significant contribution to the growing body of literature on gender mainstreaming in the energy sector.

\section{ACKNOWLEDGEMENTS}

This work is based on research by the Africa-UK Trilateral Research Chair ID SARCI18076349612, under the Newton Fund - National Research Foundation of South Africa partnership, Grant Number 120129.

\section{REFERENCES}

[1] World Health Organization. 2006. Fuel for life: Household energy and health [Online]. Available at: https://www. who.int/airpollution/publications/fuelforlife.pdf?ua=1. Accessed on: 14 April 2020.

[2] Hernández, D. 2016. Understanding "energy insecurity" and why it matters to health. Social Science and Medicine, 167, pp. 1-10.

[3] Oparaocha, S., \& Dutta, S. 2011. Gender and energy for sustainable development. Current Opinion in Environmental Sustainability, 3(4), pp. 265-271.

[4] United Nations. 2019b. The sustainable development goals report 2019 [Online]. Available at: https: //www.unilibrary.org/economic-and-social-development/the-sustainable-development-goals-report-2019_55eb9109-en. Accessed on: 14 April 2020.

[5] Barnes, D.F., Anderson, D., Jechoutek, K., \& Norma, A. 1996. Rural energy and development: Improving energy supplies for 2 billion people [Online]. Available at: http://documents1. worldbank.org/curated/en/ 841361468740715123/pdf/multi-page.pdf. Accessed on: 14 April 2020. 
[6] United Nations Development Programme. 2000. Energy and the challenge of sustainability: Energy and social issues [Online]. Available at: http://citeseerx.ist.psu.edu/viewdoc/download?doi=10.1.1.196.4978\& rep=rep1\& type=pdf. Accessed on: 15 April 2020.

[7] Reddy, A.K.N., Williams, R.H., Johansson, T.B., \& Baldwin, S. 1997. Energy after Rio: Prospects and challenges. United Nations Publications, New York.

[8] Skutsch, M.M. 2005. Gender analysis for energy projects and programmes. Energy for Sustainable Development, 9(1), pp. 37-52.

[9] Nelson, S., \& Kuriakose, A.T. 2017. Gender and renewable energy: Entry points for women's livelihoods [Online]. Available at: https://www.climateinvestmentfunds.org/sites/cif_enc/files/gender_and_re_digital.pdf. Accessed on: 15 April 2020.

[10] Clancy, J.S., Skutsch, M.M., \& Batchelor, S. 2003. The gender-energy-poverty nexus: Finding the energy to address gender concerns in development [Online]. Available at: https://esmap.org/sites/default/files/resourcesdocument/The\%20Gender\%20Energy\%20Poverty\%20Nexus.pdf. Accessed on: 15 April 2020.

[11] Sovacool, B.K. 2011. Security of energy services and uses within urban households. Current Opinion in Environmental Sustainability, 3(4), pp. 218-224.

[12] Tucker, M. 1999. Can solar cooking save the forests? Ecological Economics, 31(1), pp. 77-89.

[13] United Nations. 2019a. Progress towards the sustainable development goals [Online]. Available at: https: / / sustainabledevelopment.un.org/content/documents/24978Report_of_the_SG_on_SDG_Progress_2019. pdf. Accessed on: 17 April 2020.

[14] United Nations. 1995. Report of the fourth world conference on women in Beijing in 1995 [Online]. Available at: https://www.un.org/womenwatch/daw/beijing/pdf/Beijing\%20full\%20report\% 20E.pdf. Accessed on: 18 April 2020.

[15] Nel, D. \& Joel, C. 2019. The transformation of governance in the South African energy sector: Critical considerations for gender mainstreaming. Journal of Contemporary Management, 16(1), pp. 313-332.

[16] Govindan, M., Palit, D., Murali, R., \& Sankar, D. 2020. Gender in electricity policymaking in India, Nepal and Kenya. In G. Bombaerts, K. Jenkins, Y. Sanusi \& W. Guoyo (eds.). Energy Justice Across Borders, Cham: Springer, pp. 111-135.

[17] IRENA. 2019. Renewable energy: A gender perspective [Online]. Available at: https://www.irena.org//media/ Files/IRENA/Agency/Publication/2019/Jan/IRENA_Gender_perspective_2019.pdf. Accessed on: 18 April 2020.

[18] Winther, T., Ulsrud, K., Matinga, M., Govindan, M., Gill, B., Saini, A., Brahmachari, D., Palit, D., \& Murali, R. 2020. In the light of what we cannot see: Exploring the interconnections between gender and electricity access. Energy Research and Social Science, 60, 101334.

[19] IUCN. 2018. Gender equality and women's empowerment policy: Mainstreaming gender-responsiveness within the IUCN programme of work [Online]. Available at: https://www.iucn.org/sites/dev/files/annex_9_to_c_95_8_ iucn_gender_equality_and_womens_empowerment_policy.pdf. Accessed on: 18 April 2020.

[20] Moher, D., Liberati, A., Tetzlaff, J., \& Altman, D.G. 2009. Preferred reporting items for systematic reviews and meta-analyses: The PRISMA statement. Annals of Internal Medicine, 151(4), pp. 264-269.

[21] Liberati, A., Altman, D.G., Tetzlaff, J., Mulrow, C., Gøtzsche, P.C., Loannidis, J.P.A., Clarke, M., Devereaux, P.J., Kleijnen, J., \& Moher, D. 2009. The PRISMA Statement for reporting systematic reviews and meta-analyses of studies that evaluate health care Interventions: explanation and elaboration. PLoS Medicine, 6(7), e1000100.

[22] Gardam, J. 2014. A role for international law in achieving a gender aware energy policy. In B. Babie \& P. Leadbeter (eds.). Law as change: Engaging with the life and scholarship of Adrian Bradbrook, Adelaide: University of Adelaide Press, pp. 43-59.

[23] Crum, M., Poist, R., Carter, C.R., \& Easton, P.L. 2011. Sustainable supply chain management: evolution and future directions. International journal of physical distribution \& logistics management, 41(1), pp.46-62.

[24] Marodin, G.A., \& Saurin, T.A. 2013. Implementing lean production systems: research areas and opportunities for future studies. International Journal of Production Research, 51(22), pp. 6663-6680.

[25] Chappin, E.J.L., \& Ligtvoet, A. 2014. Transition and transformation: A bibliometric analysis of two scientific networks researching socio-technical change. Renewable and Sustainable Energy Reviews, 30, pp. 715-723.

[26] Hietschold, N., Reinhardt, R., \& Gurtner, S. 2014. Measuring critical success factors of TQM implementation successfully-a systematic literature review. International Journal of Production Research, 52(21), pp. 6254-6272.

[27] Soosay, C.A., \& Hyland, P. 2015. A decade of supply chain collaboration and directions for future research. Supply Chain Management: An International Journal, 20(6), pp. 613-630.

[28] Svejvig, P., \& Andersen, P. 2015. Rethinking project management: A structured literature review with a critical look at the brave new world. International Journal of Project Management, 33(2), pp. 278-290.

[29] Touboulic, A., \& Walker, H. 2015. Theories in sustainable supply chain management: A structured literature review. International Journal of Physical Distribution and Logistics Management, 45(1), pp. 16-42.

[30] McCartney, G., Hearty, W., Taulbut, M., Mitchel, R., Dryden, R., \& Collins, C. 2017. Regeneration and health: a structured, rapid literature review. Public Health, 148, pp. 69-87.

[31] Duong, L. N. K., \& Chong, J. 2020. Supply chain collaboration in the presence of disruptions: a literature review. International Journal of Production Research, 58(11), pp. 3488-3507.

[32] Robertson Munro, F., \& Cairney, P. 2020. A systematic review of energy systems: The role of policymaking in sustainable transitions. Renewable and Sustainable Energy Reviews, 119, 109598.

[33] Elsevier. 2019. Scopus Global Research Factsheet [Online]. Available at: https://www.elsevier.com/_data/ assets/pdf_file/0010/891397/Scopus_GlobalResearch_Factsheet2019_FINAL_WEB.pdf. Accessed on: 19 April 2020.

[34] Patriarca, R., Di Gravio, G., Woltjer, R., Costantino, F., Praetorius, G., Ferreira, P., \& Hollnagel, E. 2020. Framing the FRAM: a literature review on the functional resonance analysis method. Safety Science, $129,104827$.

[35] Gusenbauer, M. 2019. Google Scholar to overshadow them all? Comparing the sizes of 12 academic search engines and bibliographic databases. Scientometrics, 118(1), pp. 177-214. 
[36] ENERGIA. 2019. Gender in the transition to sustainable energy for all: From evidence to inclusive policies [Online]. Available at: https://www.energia.org/cm2/wp-content/uploads/2019/04/Gender-in-the-transition-to-sustainable-energy-for-all_-From-evidence-to-inclusive-policies_FINAL.pdf. Accessed on: 19 April 2020.

[37] Jusoh, S., \& Almajali, S. 2020. A Systematic Review on Fusion Techniques and Approaches Used in Applications. IEEE Access, 8, pp. 14424-14439.

[38] Moher, D., Pham, B., Klassen, T.P., Schulz, K.F., Berlin, J.A., Jadad, A.R., \& Liberati, A. 2000. What contributions do languages other than English make on the results of meta-analyses? Journal of Clinical Epidemiology, 53(9), pp. 964-972.

[39] Bustelo, M. 2003. Evaluation of Gender Mainstreaming: Ideas from a Meta-Evaluation Study. Evaluation, 9(4), pp. 383-403.

[40] Eveline, J., \& Bacchi, C. 2005. What are we mainstreaming when we mainstream gender? International Feminist Journal of Politics, 7(4), pp. 496-512.

[41] Allwood, G. 2013. Gender mainstreaming and policy coherence for development: Unintended gender consequences and EU policy. Women's Studies International Forum, 39, pp. 42-52.

[42] Cherp, A., \& Jewell, J. 2014. The concept of energy security. Energy Policy, 75, pp. 415-421.

[43] Magar, V., Heidari, S., Zamora, G., Coates, A., Simelela, P.N., \& Swaminathan, S. 2019. Gender mainstreaming within WHO: not without equity and human rights. The Lancet, 393(10182), pp. 1678-1679.

[44] Syed, J., \& Ali, F. 2019. A relational perspective on gender equality and mainstreaming. Human Resource Development International, 22(1), pp. 4-24.

[45] Rahim, A.A.A., Nurmaya Musa, S., Ramesh, S., \& Lim, M.K. 2020. A systematic review on material selection methods. Journal of Materials: Design and Applications, 0(0), pp.1-28.

[46] Snilstveit, B., Oliver, S., \& Vojtkova, M. 2012. Narrative approaches to systematic review and synthesis of evidence for international development policy and practice. Journal of Development Effectiveness, 4(3), pp. 409429.

[47] Thomas, J., Harden, A., \& Newman, M. 2012. Synthesis: combining results systematically and appropriately. In D. Gough, S. Oliver \& J. Thomas (eds.). An introduction to systematic reviews, Los Angeles: SAGE, pp.179-226.

[48] Evans, D., \& FitzGerald, M. 2002. Reasons for physically restraining patients and residents: a systematic review and content analysis. International journal of nursing studies, 39(7), pp. 735-743.

[49] Ambole, A., Musango, J.K., Buyana, K., Ogot, M., Anditi, C., Mwau, B., Kovacic, Z., Smit, S., Lwasa, S., Nsangi, G., Sseviiri, H., \& Brent, A.C. 2019. Mediating household energy transitions through co-design in urban Kenya, Uganda and South Africa. Energy Research \& Social Science, 55(1), pp 208-217.

[50] Denton, F. 2004. Reducing the gap between projects and policies: a comparative analysis of the 'butanisation' programme in Senegal and the Multifunctional Platform (MFP) experience in Mali. Energy for Sustainable Development, 8(2), pp.17-29.

[51] Morris, E., Greene, J., \& Healey, V. 2019. Blueprint guide for creating gender-sensitive energy policies [Online]. Available at: https://www.nrel.gov/docs/fy19osti/73927.pdf. Accessed on: 19 April 2020.

[52] Clancy, J. S., \& Mohlakoana, N. 2020. Gender audits: An approach to engendering energy policy in Nepal, Kenya and Senegal. Energy Research \& Social Science, 62, 101378.

[53] Ferguson, L. and Harman, S. 2015. Gender and Infrastructure in the World Bank. Development Policy Review, 33(5), pp. 653-671.

[54] Maduekwe, M., Morris, E., Greene, J., \& Healey, V. 2019. Gender equity and mainstreaming in renewable energy policies-empowering women in the energy value chain in the Economic Community of West African States (ECOWAS). Current Sustainable/Renewable Energy Reports, 6(1), pp. 13-21.

[55] Prebble, M. and Rojas, A. 2017. The enabling power of energy in promoting gender equality: Gender in the SEforALL country action process documents [Online]. Available at: https://www.climatelinks.org/sites/default/ files/asset/document/2017_IUCN-AGENT_EGI-SEforALL-accessible.pdf. Accessed on: 19 April 2020.

[56] Prebble, M. and Rojas, A. 2018. Energizing equality: Sub-Saharan Africa's integration of gender equality principles in national energy policies and frameworks [Online]. Available at: https://www.climatelinks.org/sites/ default/files/asset/document/2018_IUCN_Energizing-Equality-Sub-Saharan-Africa\%27s-Integration-of-GenderEquality-Principles-Energy-Policies_accessible.pdf. Accessed on: 19 April 2020.

[57] Molony, T. 2011. Bioenergy policies in Africa: mainstreaming gender amid an increasing focus on biofuels. Biofuels, Bioproducts and Biorefining, 5(3), pp. 330-341.

[58] Dutta, S., Kooijman, A., \& Cecelski, E. 2017. Energy Access and Gender: Getting the Right Balance [Online]. Available at: http://documents1.worldbank.org/curated/en/463071494925985630/pdf/115066-BRI-P148200PUBLIC-FINALSEARSFGenderweb.pdf. Accessed on: 19 April 2020.

[59] Winther, T., Ulsrud, K., \& Saini, A. 2018. Solar powered electricity access: Implications for women's empowerment in rural Kenya. Energy Research and Social Science, 44, pp. 61-74.

[60] Khan, M. 2016. Policy review and recommendations on the promotion of renewable energy and energy efficiency [Online]. Available at: https://www.solarthermalworld.org/sites/gstec/files/news/file/2017-01-25/pakistan_ reee_policy_reviewadvisory_first_draft_2.pdf. Accessed on:19 April 2020.

[61] Slini, T., Giama, E., \& Pavlidou, F.N. 2016. Energy policies: the gender approach [Online]. Available at: https://www.researchgate.net/publication/304314904_Energy_policies_the_gender_approach. Accessed on: 19 April 2020.

[62] Parshotam, A. 2018. Opportunities and Challenges in Engendering the African Energy [Online]. Available at: https://media.africaportal.org/documents/GA_Th1_PB_Parshotam_20181029.pdf. Accessed on: 20 April 2020.

[63] Pueyo, A., Maestre, M., Carreras, M., Bawakyillenuo, S., \& Ngoo, G. 2019. Unlocking the Benefits of Productive Uses of Energy for Women in Ghana, Tanzania and Myanmar: ENERGIA [Online]. Available at: https://www.energia.org/cm2/wp-content/uploads/2019/03/RA6-Unlocking-the-benefits-of-productive-uses-ofenergy.pdf. Accessed on: 20 April 2020. 
[64] Clancy, J., Mohlakoana, N., \& Gueye, Y.D. 2016. Mainstreaming gender in energy sector practice and policy: lessons from the ENERGIA International Network [Online]. Available at: https://www.energia.org/cm2/wpcontent/uploads/2016/12/Mainstreaming-gender-in-energy-sector-policy-and-practice_FULL-REPORT.pdf. Accessed on: 20 April 2020.

[65] Permana, A.S., Aziz, N., \& Siong, H. 2015. Is mom energy efficient? A study of gender, household energy consumption and family decision making in Indonesia. Energy Research and Social Science, 6, pp. 78-86.

[66] De Groot, J., Mohlakoana, N., Knox, A., \& Bressers, H. 2017. Fuelling women's empowerment? An exploration of the linkages between gender, entrepreneurship and access to energy in the informal food sector. Energy Research and Social Science, 28, pp. 86-97.

[67] Kooijman, A., Cloke, J., \& Clancy, J. 2018. Needs, wants and values: integrating gender with energy access, ENERGIA [Online]. Available at: https://www.energia.org/cm2/wp-content/uploads/2019/03/Final-Gender_LowCarbon-Energy-Network-Briefing-Paper-3-AW-web.pdf. Accessed on: 21 April 2020.

[68] Pueyo, A., \& Maestre, M. 2019. Linking energy access, gender and poverty: A review of the literature on productive uses of energy. Energy Research and Social Science, 53 pp. 170-181.

[69] Clancy, J., \& Mohlakoana, N. 2016. Gender and energy research: Building the evidence base for improving energy interventions' effectiveness, ENERGIA [Online]. Available at: https://www.energia.org/cm2/wp-content/ uploads/2014/11/Energia-News-May-2016-final-lr.pdf. Accessed on: 21 April 2020.

[70] Johnson, O. W., Gerber, V., \& Muhoza, C. 2019. Gender, culture and energy transitions in rural Africa. Energy Research and Social Science, 49, pp. 169-179.

[71] Fingleton-Smith, E. 2018. The lights are on but no (men) are home: The effect of traditional gender roles on perceptions of energy in Kenya. Energy Research \& Social Science, 40(1), 211-219.

[72] Lee, N., \& Arent, D. 2019. Introduction to the Topical Collection on Regional Renewable Energy. Current Sustainable/Renewable Energy Reports, 6(1), pp. 1-4. 